\title{
Role of traditional and new biomarkers in breast carcinogenesis
}

\author{
D Macis $^{1}$, M Cazzaniga ${ }^{1}$, A De Censi $^{1,2}$ and B Bonanni ${ }^{1}$ \\ ${ }^{1}$ Division of Cancer Prevention and Genetics, European Institute of Oncology, via Ripamonti 435, 20141 Milan, Italy \\ ${ }^{2}$ Division of Medical Oncology, E O Ospedali Galliera, Genoa, Italy
}

\begin{abstract}
In recent decades, several biomarkers have been investigated as predictors of breast cancer risk, development, prognosis and treatment efficacy.

The detection of biomarkers strongly associated with breast carcinogenesis has an enormous potential, especially for selecting subjects at high risk of developing breast cancer who could benefit from chemopreventive treatments.

Although the number of potential biomarkers continues to increase, a unique biomarker for breast cancer risk prediction has not been identified and it is probable that a panel of biomarkers will prove optimal. Further studies are needed to validate breast cancer biomarkers evaluation for individual risk assessment.

This review summarizes the main biomarkers, which are important at different stages of breast carcinogenesis with updates from the recent literature.
\end{abstract}

Published: 29/10/2009

Received: 24/09/2009

ecancer 2009, 3:157 DOI: 10.3332/ecancer.2009.157

Copyright: (c) the authors; licensee ecancermedicalscience. This is an Open Access article distributed under the terms of the Creative Commons Attribution License (http://creativecommons.org/licenses/by/2.0), which permits unrestricted use, distribution, and reproduction in any medium, provided the original work is properly cited.

Competing Interests: The authors have declared that no competing interests exist.

Correspondence to B Bonanni. Email: bernardo.bonanni@ieo.it 


\section{Introduction}

Efficacy in breast cancer early diagnosis, treatment and prevention is a big challenge considering that breast cancer is the most common diagnosed cancer in women worldwide. Biomarkers have a critical role both in monitoring cancer progression and assisting the identification of high-risk subjects. The general characteristics of a biomarker should include high reproducibility and detectability, easy collection from patients by minimally invasive techniques and high correlation with the disease with different expression in healthy versus affected subjects.

An ideal biomarker for monitoring cancer treatment should be strongly correlated with cancer growth and should be an index for drug efficacy. A good candidate biomarker for cancer prevention would be a marker directly correlated with risk and with molecular mechanisms of carcinogenesis in pre-cancerous tissues, should be differentially expressed in average versus high-risk populations and should predict response to chemopreventive agents. Several tumour markers have shown evidence of clinical usefulness and have been recommended for use in practice in breast cancer patients: CA 15-3, CA 27.29, carcinoembryonic antigen (CEA), oestrogen and progesterone receptors (ER, $P R)$, human epidermal growth factor receptor 2 (HER-2), urokinase plasminogen activator (UPA), plasminogen activator inhibitor 1 (PAI-1) and certain multiparametre gene expression assays (Oncotype DX, MammaPrint, Rotterdam Signature) [1].

In the last decade, much effort has been focused on discovering biomarkers that can be used to predict breast cancer risk. Among the established risk biomarkers, deleterious germline mutations in BRCA1/BRCA2/TP53 genes have been demonstrated as strong predictors of breast cancer development [2] and recent studies have also investigated the possible association between single nucleotide polymorphisms (SNPS) and breast cancer risk [3-5]. An association between levels of endogenous sex hormones with breast cancer risk have been shown in post-menopausal women [6,7], whereas other hormones and circulating biomarkers such as serum IGF1, IGFBP-3 and also testosterone have been demonstrated to be associated with risk, especially in pre-menopausal women, although more recent data have also demonstrated relevance in post-menopause [8-12].

Other potential biomarkers that have been investigated for an association with breast cancer include hormonal and nuclear receptors, membrane receptors and signal transduction factors, anti-inflammatory and antioxidant factors, apoptosis and angiogenesis factors, proliferation markers and antigens, epigenetic modulation factors, cellular inducible enzymes, cell cycle regulators, oncogenes and tumour suppressor genes $[13,14]$.

In this review, we will discuss the main biomarkers which have been reported to have a role in breast cancer early development and progression.

\section{Hormonal and nuclear receptors}

Oestrogen and progesterone are essential hormones for breast growth, and their receptors (ER and PR) are established predictive factors for breast cancer treatment efficacy and disease outcome. ERs are transcription factors, which mediate the action of oestrogens, whereas the PR gene is regulated by oestrogen, and so the PR could be a marker of oestrogen action in breast cancer [15].

Previous studies have shown that ER and PR levels are associated with a favourable breast cancer prognosis and are highly predictive of benefit from endocrine treatment in both the adjuvant and metastatic settings [16-18]. Two different isoforms for each receptor have been described: ERa. and ERb; PRA and PRB. Functional experiments have demonstrated that ERa and $\mathrm{ERb}$ have completely different roles in breast cancer: ERa acts as a tumour promoter, whereas ERb is a tumour suppressor. The presence of $\mathrm{ERb}$ in breast tumours is associated with better prognosis and longer disease-free survival [19]. ERa expression has been demonstrated to be increased in normal epithelium taken from a tumour-bearing breast [20], and another study reported increased ERa expression in the tissue of women at high risk of developing breast cancer [21]. However, it is important to consider the relative amounts of $\mathrm{ERa}$ and $\mathrm{ERb}$; as normal breast tissue becomes tumourigenic, the amount of ERa increases whereas the amount of ERb decreases [22].

In normal breast, PRA and PRB are co-expressed at similar levels on luminal epithelial cells, suggesting that both proteins are required to mediate physiologically relevant progesterone signalling, and an imbalance in the native ratio of the two isoforms may lead to alterations in PR signalling [23,24]. Previous studies have demonstrated that the ratio between PRA and PRB is altered during the breast carcinogenesis process $[25,26]$.

Androgen receptors (AR) are expressed by the majority of human breast carcinomas, at a frequency comparable to or 
higher than that reported for ER and PR $[27,28]$. AR shows a statistically significant association with important clinical and pathologic prognostic factors [29], such as histopathological grade, tumour invasiveness and axillary lymph node involvement [30-33]. Furthermore, some studies reported statistically significant associations between increased levels of testosterone and higher breast cancer risk in both pre- and post-menopausal healthy women [11,34-36], supporting a role for androgens and their receptors in breast carcinogenesis.

All these findings highlight the role of $E R, P R$ and $A R$ in promoting breast cancer and consequently their potential as drug targets in both preventive and therapeutic settings.

Other members of the steroid/thyroid hormone receptor super family include the nuclear retinoid receptors. Receptor selective retinoids inhibit the growth of both normal and cancerous human breast cells predominantly through induction of a G1 cell cycle block [37]. There are two classes of retinoid receptors: retinoic acid receptors (RARs) and retinoid X receptors (RXRs). Both types of receptors are encoded by three distinct genes $a, b$ and $\mathrm{g}$. Their functional activities require dimerisation with a member of the nuclear non-steroidal receptor family, in particular RXRs dimerise with peroxisome proliferator-activated receptors (PPARs) and with the vitamin D receptor (VDR) [3840].

The RARs and RXRs are thought to mediate the effects of retinoids on cell growth, differentiation and apoptosis and, therefore, to have a role in mammary carcinogenesis suppression [41-43]. RARa expression has been demonstrated to be positively linked to proliferative activity and to ER expression [44], whereas RARb may act as a tumour repressor gene, since its expression is progressively lost with increasing proliferative activity of the tumour [45]. Furthermore, an increasing RARa/RARb ratio may be a marker of progression from the pre-invasive to the invasive state in breast cancer [46].

The PPARs are also members of the nuclear receptor super family, which includes steroid, retinoid and thyroid hormone receptors $[47,48]$. Three isoforms of PPAR have been identified, $a, d$ and $g$. PPARg has been found to be expressed in normal breast epithelium and breast cancers [49]. It heterodimerises with RXR and then binds to the peroxisome proliferator response elements in the promoter regions of targets genes, allowing for activation of gene transcription that is responsible for cell cycle modulation, cellular differentiation, decreased proliferation and inhibition of angiogenesis [50,51].
Previous studies suggested that PPARg signalling may exacerbate mammary gland tumour development in mice [52] and PPARg ligands have been shown to inhibit the proliferation and induce the apoptosis of breast cancer cell lines in vitro through the activation of PPARg [53]. Furthermore, a favourable impact of PPARg expression on disease-free survival of patients with ductal breast carcinoma, and its possible cooperation with ERb in exerting that favourable effect has been reported [54].

All these results document important roles for retinoid receptors and PPARs in oncogenesis, thereby identifying new targets for cancer therapy and prevention. Further evidence supporting the importance of the retinoid pathway in breast cancer development has been provided by a large randomised trial with the synthetic retinoid fenretinide that has shown a reduced risk of recurrence after primary surgery in pre-menopausal women [55].

The vitamin $\mathrm{D}$ receptor is a nuclear receptor present on over $80 \%$ of human breast cancers and mediates the action of 1,25 dihydroxy-vitamin $D_{3}$, the biologically active form of vitamin $D$, that modulates differentiation, cell cycle and apoptosis of stromal and epithelial cells derived from mammary gland and breast cancers in vitro [56-60]. A vitamin D analogue significantly enhanced the ability of tamoxifen to prevent mammary tumours in rats, suggesting that vitamin D compounds and anti-oestrogenic compounds might protect against breast cancer through independent mechanisms [61].

The expression patterns of the heterodimers formed by VDR and RARs or RXRs have been studied by immunohistochemistry in benign and malignant human breast tissues. Higher levels of all receptor types were found in both in situ and infiltrative carcinomas compared to benign breast diseases or normal breast tissue [62,63]. Previous studies on VDR expression and its relationship with breast cancer prognosis indicated a longer disease-free survival in patients with VDR positive tumours compared to those with VDR negative neoplasms $[60,64]$. An inverse correlation between vitamin $\mathrm{D}$ intake and breast cancer risk has been observed in several studies [65-67] and also low serum 1,25-dihydroxyvitamin $D_{3}$ has been correlated with increased breast cancer risk and metastasis $[68,69]$.

Several epidemiologic, mechanistic and experimental data support the chemopreventive potential of vitamin $D$ and its analogues, although hypercalcemic side effects represent a major obstacle to their clinical development. A proposed strategy for using a non-calcemic dose in the chemopreventive setting is to administer vitamin D or its analogues in 
combinations with other agents, such as retinoids or antioestrogenic compounds [70].

\section{Membrane receptors and signal transduction factors}

Tyrosine kinase signalling has been demonstrated to have an important role in the genesis and progression of human breast cancer as well as in all the steps of the normal mammary gland development [71]. Receptor tyrosine kinases (RTK) belong to a class of transmembrane receptors composed of nearly 60 members distributed among 20 subfamilies. A little more than half of the known RTKs have been repeatedly found in either mutated or over-expressed forms to be associated with human malignancies, including sporadic cases [72,73]. The most studied receptors of this super family are the human epidermal growth factor receptors, which belong to subclass I, comprising four members (HER1, HER2, HER3, HER4). The epidermal growth factor receptor (EGFR or HER1) has been demonstrated to be involved in malignant transformation and cancer progression and its over-expression in cancer tissues has been associated with a more aggressive phenotype and a worse survival $[74,75]$. Nearly $45 \%$ of human breast tumours express EGFR and previous studies reported an inverse correlation between EGFR and ER expression in breast cancer [76,77]. EGFR and ER are also frequently co-expressed in normalappearing cells obtained from breast cancer patients [78]. Moreover, Fabian et al found a significantly higher expression of EGFR in ductal cells of needle aspirates from women at high risk for breast cancer development than in low-risk control subjects [79], suggesting EGFR as a viable target for breast cancer chemoprevention.

The HER2 gene is amplified and over-expressed in about 25\% of breast cancers, conferring a more aggressive biology [80]. Over-expression of the HER2 gene is associated with rapid tumour growth, increased risk of recurrence after surgery, poor response to conventional chemotherapy and shortened survival [81].

It has been reported that tamoxifen treatment up-regulates HER2 by $40 \%$ in breast cancer cells expressing both HER2 and ER [82], and that when HER2 is co-expressed with ERa, the patients show a shorter disease-free survival and overall survival [83]. These findings suggest that HER2 modulation is an ER-mediated process.

The other two members of the HER family, HER3 and HER4, are of particular interest because of their ability to interact directly with HER2. A recent study presented striking evidence that alterations in HER3 exist in breast cancer [84] and another study demonstrated that blocking HER2 resulted in antiproliferative effects accompanied by a decrease in HER3 signalling activity [85]. Furthermore, HER3 contributes to HER2associated tamoxifen resistance and a decrease in HER3 levels restores sensitivity to tamoxifen [86] and gefitinib (an EGFR tyrosine kinase inhibitor) has been demonstrated to decrease EGFR and HER3 phosphorylation through the inhibition of EGFR/HER3 dimerisation [87]. HER4 protein over-expression has previously been described as a positive prognostic factor in breast tumours [88-90]. HER4 amplification detected by FISH was found to be correlated with a positive oestrogen receptor status [84,91], whereas conflicting conclusions were reported by other authors who found that HER4 amplification and ER activity were negatively correlated [92]. These differences may be due to the variable responses by HER4 to its activating ligand Heregulin, resulting in either proliferation or differentiation, and perhaps influenced by homodimerisation or heterodimerisation with other HER family members [93].

Two other membrane receptors demonstrated to have a role in breast carcinogenesis are the transforming growth factor beta (TGF-b) receptor and the insulin-like growth factor (IGF) receptors. TGF-b signalling pathway is implicated in cell senescence, regulation of cell growth and differentiation [94]. TGF-b has a dual role: in normal development, it inhibits cell proliferation by induction of apoptosis and cell cycle arrest and promotes cell differentiation, whereas during tumourigenesis TGF-b secreted from tumour cells often loses its inhibitory function in favour of its oncogenic activity [95]. Increased production of TGF-b occurs in different tumour types and correlates with the severity of the tumour grade [96,97]. Since the role of TGF-b pathway in carcinogenesis has been elucidated, specific molecular inhibitors, such as TGF-b antibodies and antisense oligonucleotides that block TGF-b receptor have been investigated in pre-clinical and clinical studies for cancer therapy $[98,99]$. Recent studies demonstrated the efficacy of TGF-b inhibitors in reducing the in vivo bone metastatic capacity of human breast cancer cells [100-102].

Another recent study reported that TGF-b is a potential mediator of retinoic acid and tamoxifen-induced apoptosis in breast cancer cell lines, suggesting that the TGF-b pathway may have a role also in the breast chemoprevention setting [103].

The IGFs are peptide hormones involved in regulation of cell proliferation, differentiation and apoptosis [104]. Several studies investigating the relationship between the circulating concentration of IGF-I and IGFBP-3 and breast cancer risk demonstrated a correlation between increasing IGF-I and 
IGFBP-3 levels and increased breast cancer risk, especially in pre-menopausal [8-10] and more recently also in postmenopausal women [12]. Anti-oestrogens, effective in breast cancer treatment and prevention, reduce serum IGF-I levels [105]. IGF-I receptors are over-expressed in many breast cancers [106], and recent clinical trials have investigated the effectiveness of IGF-I receptor inhibitors in cancer therapy [107]. Circulating IGF-I mainly binds to IGFBP-3, a protein that regulates the mitogenic actions of IGFs and inhibits their apoptotic effect and also has an IGF-independent inhibitory effect on cell growth [104]. Baxter and co-worker showed that IGFBP-3 production is potently induced by TGF-b and proposed a role for IGFBP-3 in mediating TGF-b inhibitory activity $[108,109]$. IGFBP3 is also a ligand for the nuclear RXR-a receptor, which was shown to be necessary for IGFBP-3 induced apoptosis [110]. Results from a phase III breast cancer prevention trial with fenretinide, suggested that the reduction of IGF-I and IGFBP-3 levels may in part explain the cancer risk reduction observed in women $\leq 50$ years of age [111].

\section{Inflammation and oxidation markers}

Cyclooxygenase-2 (COX-2) is an important inflammatory mediator, responsible for the conversion of arachidonic acid into prostaglandins. In the last decade, several studies reported a correlation between COX-2 expression and breast cancer. Elevated COX-2 protein levels have been detected in approximately $40 \%$ of invasive breast cancers and COX-2 overexpression has been demonstrated to correlate with large tumour size, high grade, high proliferation, hormone receptor negative status and over-expression of HER-2 [112-117]. The role of COX-2 in breast cancer pathogenesis suggested the COX-2 signalling as a target for breast cancer treatment and prevention. Some meta-analyses and case control studies reported a moderate reduction in risk of breast cancer, up to 24\%, with non-steroidal anti-inflammatory drugs (NSAIDs) [118120]. Pre-clinical studies suggested that celecoxib, which is a selective inhibitor of COX-2, is effective in both preventing and treating breast cancer in a dose-dependent manner [121,122]. However, other trials have identified an increased cardiovascular risk associated with COX inhibitors, probably due to their selective depression of prostacyclin levels [123]. Sauter et al investigated the possible correlation between celecoxib administration and prostaglandin concentration in serum and nipple aspirate fluid (NAF), reporting a reduction of prostaglandin levels in NAF of post-menopausal high-risk women and a reduction in both NAF and plasma prostaglandin levels in women with newly diagnosed breast cancer [124].
Further clinical trials are necessary to better understand the chemopreventive and treatment potential of celecoxib.

Matrix metalloproteinases (MMPs) are a family of proteases involved in the regulation of the cell microenvironment, matrix turnover, growth factor bioavailability and several aspects of immunity and inflammation. Other classes of proteases, which interact with MMPs are a disintegrin and metalloproteinases (ADAMs), and tissue inhibitor of metalloproteinases (TIMPS) $[125,126]$. Epidemiological evidence suggests an association between inflammation and breast cancer and several studies investigating the role for MMPS, ADAMs and TIMPs in breast cancer risk and progression have demonstrated that high levels of MMP9 are associated with poor breast cancer prognosis $[127,128]$. MMP1 may prove be a breast cancer risk marker since it has been found in tissues with atypical ductal hyperplasia and in ductal lavage cells from patients at risk for developing breast cancer [129]. Other studies reported that TIMP1 levels correlate positively with higher serum HER-2 levels, increased metastasis and reduced survival in breast cancer patients [130], whereas TIMP3 over-expression was associated with successful adjuvant endocrine therapy, good prognosis and longer disease-free survival [131-133]. Some evidence also suggests a role for TIMP3 as a breast cancer risk marker as TIMP3 levels were higher in mammographically dense breasts, which are considered to be at higher risk for developing breast cancer [134]. Although the biology of ADAMs is less understood than that of MMPs, several components of this family have been found in breast cancer and, in particular, ADAM9 correlates positively with HER-2 levels [135] and with positive response to tamoxifen [136]. Furthermore, ADAM12 urine levels have been found to positively correlate with breast cancer progression, suggesting a possible diagnostic role [136].

C-reactive protein (CRP) is an acute-phase protein, synthesized in the liver, which is considered a marker of inflammation [137]. CRP serum levels have been associated with breast cancer and increased circulating levels of CRP have also been detected in more advanced stages of breast malignancy [138], suggesting the potential use of CRP as a biomarker of disease prognosis [139]. Elevated levels of CRP are associated with reduced survival in breast cancer patients [140-142]. In the Rotterdam Study, a statistically significant increase in breast cancer risk associated with higher CRP levels at baseline was reported [143], whereas other authors did not find any significant association between circulating $\mathrm{CRP}$ and breast cancer risk [144-146]. In a recent study, the relation between the level of CRP protein in NAF and breast cancer risk as predicted by the Gail model was investigated. CRP was found in NAF samples, and it was not significantly related to serum CRP levels, 
suggesting that CRP presence in NAF may reflect the early development of proliferative changes in the ductal epithelium preceding carcinoma in situ and invasive carcinoma [147].

Osteopontin (OPN) is a phosphoglycoprotein involved in a variety of physiopathologic processes such as bone remodelling, angiogenesis, inflammatory response, cell growth and tissue differentiation and wound healing [148]. OPN positivity of the primary breast tumour is significantly associated with decreased survival $[149,150]$ and recent studies by Mirza et al suggested that the OPN-c splice variant could be a selective and prognostic marker for human breast cancer, as OPN-c mRNA was identified in $80 \%$ of breast carcinomas [151]. Patani et al demonstrated a significant positive association of OPN-b and OPN-c expression with adverse pathological and clinical outcomes [152].

In a cohort of women with newly diagnosed metastatic breast cancer, high-baseline OPN plasma levels or OPN increase > $250 \mathrm{ng} / \mathrm{ml}$ at any time during follow-up were found to be associated with poor survival [153] and higher OPN levels in patients with metastatic breast cancer may be associated with an increased number of involved sites and decreased survival [154].

\section{Apoptosis, cell cycle regulators and angiogenesis factors}

The apoptosis-signalling pathway has an important role in cancer onset and progression. Many apoptotic proteins have been studied for an association with breast cancer pathogenesis. The inhibitors of apoptotic proteins are a more recently described family of proteins that function as endogenous inhibitors of caspases [155]. Survivin is the only member of this family, which has a dual role in inhibition of apoptosis and regulation of mitosis [156]. Data from a large analysis of human transcripts reported a higher expression of survivin in cancer tissues compared with normal tissues [157]. In an immunohistochemical study, survivin over-expression was detected in surgically resected primary tumour specimens of breast cancers [158], and recent studies reported that survivin is linked to aggressive breast cancers [159], resistance to apoptosis [160] and modulation of HER-2 signalling [161]. Few studies investigated the possible association between survivin and histological parameters or prognostic factors with controversial results: some of them reported no association between tissue and serum survivin expression and tumour size, p53 expression, oestrogen and progesteron receptors levels [162-164], while others showed that high-tissue survivin expression was correlated with high-nuclear grade, negative hormone receptor status and HER-2 over-expression [165], and that the presence of survivin is a highly significant independent predictor of shorter duration of survival in patients with poor prognostic features [166]

TP53 is a tumour suppressor gene that encodes the p53 protein, which is activated in response to several forms of cellular stress and mediates many cellular processes, including cell cycle arrest, apoptosis, senescence and differentiation $[167,168]$. Several studies have investigated the predictive value of TP53 mutations for tumour response to treatment and patient outcome in various cancers and for breast cancer the presence of a mutation was reported to correlate with shorter survival or a poor outcome $[169,170]$. TP53 mutation status was also shown to be useful to identify women at higher risk of disease recurrence and death when their tumour had a HER2 gene amplification [171].

P53 has been shown to be a possible target of the immune system. Antibodies against p53 have been detected in different types of malignant disease, with the highest positivity rates observed for breast cancer [172]. There are studies reporting a significant correlation between presence of p53 antibodies and the detection of mutated p53 protein in tissue sections and higher serum levels of antibodies in breast cancer cases than in healthy subjects from the general population. Furthermore, in breast cancer patients the presence of p53 antibodies also indicated a shortened survival [173-175].

Cyclin D1 is a key factor involved in the regulation of the G1-S phase transition during the cell cycle. Cyclin D1 over-expression has been observed in DCIS, suggesting a possible role in breast cancer development [176-178]. Previous studies have reported that in ER-positive breast cancer patients, cyclin D1 over-expression is associated with overall and relapse-free survival $[179,180]$.

It has been shown that cyclin D1 can activate oestrogen receptor transcriptional activity in the absence of estradiol, and that this activity can be inhibited by 4-hydroxytamoxifen [181]. Furthermore, published in vitro data suggested that retinoids reduce cyclin D1 expression in human breast cancer cell lines $[182,183]$. These data are of great interest, since fenretinide has shown to induce a significant risk reduction of second breast cancer in pre-menopausal women, suggesting a possible role as breast cancer chemopreventive agent in high-risk young women [184].

Vascular endothelial growth factor (VEGF) is a key enhancer factor of angiogenesis, the process of new blood vessels formation, involved in cancer development and progression. 
Several studies have investigated the association between VEGF expression in cancer tissues and plasma with breast cancer. High levels of VEGF expression in breast cancer tissues have been associated with poor prognosis and decreased overall survival $[185,186]$, and many authors have reported that circulating VEGF levels are increased among breast cancer women [187-189]. It has been suggested that VEGF expression may help predict the biologic aggressiveness of DCIS [190]. VEGF over-expression was found not only in DCIS, but also before remodelling of the fibroblastic stroma of pre-malignant breast lesions [191]. Furthermore, previous studies evaluating VEGF expression and angiogenesis in breast cancer patients, have reported that sex steroids regulate angiogenesis and increase VEGF expression [192], whereas the agonist of the oestrogen receptor tamoxifen has been shown to decrease VEGF expression and angiogenesis $[187,189,193]$.

\section{Proliferation markers and antigens}

Several studies have been conducted to investigate the possible use of proliferation markers as breast cancer prognostic indicators. Various methods are available for the measurement of proliferation rates in tumours, including mitotic counts, estimation of the fraction of cells in S-phase of the cell cycle and proliferation-associated antigens [194]. A previous study reported that mitotic count was a stronger predictor of survival than tumour size and lymphatic or skin invasion [195]. However, one limitation of mitotic index as a measure of proliferation is that the duration of the mitotic phase of the cell cycle is variable and consequently the correlation of number of mitoses and proliferation rate is not necessarily linear [196]. The measurement of the fraction of cells in chromosomal DNA synthesis (the S-phase of cell cycle) is one of the standard methods of assessing proliferation, with various techniques that can detect DNA replication. Recently, alternative methods of assessing proliferation that are based on the detection of nuclear antigens by immunohistochemistry have been investigated. Ki67, a protein expressed in the nucleus during the cell cycle, is actually used as measure of proliferation [194]. It has been demonstrated that Ki67 correlates significantly with estimates of the mitotic count index and the measurement of the fraction of cells in S-phase $[197,198]$. Several studies reported an association between Ki67 and disease-free and overall survival, with an increased risk of recurrence in tumours with a high Ki67 [199-201]. Several authors measured Ki67 in tamoxifen-treated breast cancer patients, all reporting a decrease in Ki67 [202-204]. Ki67 has been validated as a surrogate endpoint biomarker reflecting the superiority of anastrozole versus tamoxifen in early stage breast cancer, with a greater reduction in Ki67 being achieved with anastrozole [205]. In recent studies, Ki67 was measured either in random periareolar fine needle aspiration and in ductal lavage samples from women at high risk of developing breast cancer, and it was reported a significant association between Ki67 expression and atypia and cell yield, indicating Ki67 as a surrogate biomarker in early-phase chemoprevention trials [206,207].

Proliferating cell nuclear antigen (PCNA), a nuclear protein involved in DNA repair processes, has been investigated, but appear to correlate poorly with Ki67 and mitotic count, suggesting a more limited use in assessing proliferation [208].

\section{Conclusions}

The biomarkers that have been discussed in this review are involved at different stages of the breast carcinogenesis multistep process. Each of the described biomarkers may be a target for drug treatment or prevention. Notwithstanding, we should take into account that the absolute benefit of a treatment varies greatly between individuals. Biomarkers may also be helpful for identification of high-risk subjects who will benefit from a given treatment. However, the currently available data do not support the implementation of a cancer risk model based on biomarkers evaluation. Further studies and prospective clinical randomised trials are necessary to better define whether and which biomarkers could be used in clinical practice for better treatment selection and patient follow-up. 


\section{References}

1. Harris L, Fritsche H, Mennel R, Norton L, Ravdin P et al (2007) American Society of Clinical Oncology 2007 update of recommendations for the use of tumour markers in breast cancer J Clin Oncol 25 5287-5312. PMID: 17954709 doi:10.1200/JCO.2007.14.2364

2. Antoniou A, Pharoah PD, Narod S, Risch HA, Eyfjord JE et al (2003) Average risks of breast and ovarian cancer associated with BRCA1 or BRCA2 mutations detected in case Series unselected for family history:a combined analysis of 22 studies $A m$ J Hum Genet 721117-1130. PMID: 12677558 doi:10.1086/375033

3. Garcia-Closas M, Hall P, Nevanlinna H, Pooley K, Morrison $\mathrm{J}$ et al (2008) Heterogeneity of breast cancer associations with five susceptibility loci by clinical and pathological characteristics PLoS Genet 4:e1000054 PMID: 18437204 doi:10.1371/journal.pgen.1000054

4. Easton DF, Pooley KA, Dunning AM, Pharoah PD, Thompson D et al (2007) Genome-wide association study identifies novel breast cancer susceptibility loci Nature 447 1087-1093 PMID: 17529967 doi:10.1038/ $\underline{\text { nature05887 }}$

5. Cox A, Dunning AM, Garcia-Closas M, Balasubramanian S, Reed MW et al (2007) A common coding variant in CASP8 is associated with breast cancer risk Nat Genet 39 352-358 PMID: 17293864 doi:10.1038/ng1981

6. Yager JD and Davidson NE (2006) Estrogen carcinogenesis in breast cancer N Engl J Med 354270 282 PMID: 16421368 doi:10.1056/NEJMra050776

7. Key T, Appleby P, Barnes I and Reeves G (2002) Endogenous sex hormones and breast cancer in postmenopausal women:reanalysis of nine prospective studies J Natl Cancer Inst 94 606-616 PMID: 11959894

8. Hankinson SE, Willett WC, Colditz GA, Hunter DJ, Michaud DS, Deroo B, Rosner B, Speizer FE and Pollak M (1998) Circulating concentrations of insulin-like growth factorI and risk of breast cancer Lancet 351 1393-1396 PMID: 9593409 doi:10.1016/S0140-6736(97)10384-1

9. Renehan AG, Zwahlen M, Minder C, O'Dwyer ST, Shalet SM and Egger M (2004) Insulin-like growth factor (IGF)-I, IGF binding protein-3, and cancer risk:systematic review and meta-regression analysis Lancet 3631346 1353 PMID: 15110491 doi:10.1016/S0140-6736(04)16044$\underline{3}$

10. Fletcher O, Gibson L, Johnson N, Altmann DR, Holly JM et al (2005) Polymorphisms and circulating levels in the insulin-like growth factor system and risk of breast cancer:a systematic review Cancer Epidemiol Biomarkers Prev 14 2-19 PMID: 15668470
11. Micheli A, Muti P, Secreto G, Krogh V, Meneghini E, Venturelli E, Sieri S, Pala V and Berrino F (2004) Endogenous sex hormones and subsequent breast cancer in premenopausal women Int J Cancer 112312 318 PMID: 15352045 doi:10.1002/ijc.20403

12. Barnes BB, Chang-Claude J, Flesch-Janys D, Kinscherf $R$, Schmidt M, Slanger T, Bonaterra G and Steindorf K (2009) Cancer risk factors associated with insulin-like growth factor (IGF)-I and IGF-binding protein-3 levels in healthy women:effect modification by menopausal status Cancer Causes Control PMID: 19597750

13. Janssens JP, Verlinden I, Gungor N, Raus J and Michiels L (2004) Protein biomarkers for breast cancer prevention Eur J Cancer Prev 13 307-317 PMID: 15554559 doi:10.1097/01.cej.0000136568.86245.b7

14. Kelloff GJ, Lippman SM, Dannenberg AJ, Sigman CC, Pearce HL et al (2006) Progress in chemoprevention drug development:the promise of molecular biomarkers for prevention of intraepithelial neoplasia and cancer--a plan to move forward Clin Cancer Res 12 3661-3697 PMID: 16778094 doi:10.1158/1078-0432.CCR$\underline{06-1104}$

15. Horwitz KB, McGuire WL. (1975) Predicting response to endocrine therapy in human breast cancer:a hypothesis. Science 189:726-727. PMID: 168640 doi:10.1126/science. 168640

16. Clark GM, McGuire WL, Hubay CA, Pearson $\mathrm{OH}$, Carter AC. (1983) The importance of estrogen and progesterone receptor in primary breast cancer. Prog Clin Biol Res 132E:183-190. PMID: 6647468

17. (2005) Effects of chemotherapy and hormonal therapy for early breast cancer on recurrence and 15-year survival:an overview of the randomised trials Lancet 365 1687-1717 PMID: 15894097 doi:10.1016/S0140$\underline{6736(05) 66544-0}$

18. Ravdin PM, Green S, Dorr TM, McGuire WL, Fabian C et al (1992) Prognostic significance of progesterone receptor levels in estrogen receptor-positive patients with metastatic breast cancer treated with tamoxifen:results of a prospective Southwest Oncology Group study J Clin Oncol 10 1284-1291 PMID: 1634918

19. Chen GG, Zeng $Q$ and Tse GM (2008) Estrogen and its receptors in cancer Med Res Rev 28 954-974 PMID: $\underline{18642351}$ doi:10.1002/med.20131

20. Khan SA, Rogers MA, Obando JA and Tamsen A (1994) Estrogen receptor expression of benign breast epithelium and its association with breast cancer Cancer Res 54 993-997. PMID: 8313390

21. Lawson JS, Field AS, Champion S, Tran D, Ishikura $\mathrm{H}$ and Trichopoulos D (1999) Low oestrogen receptor alpha 
expression in normal breast tissue underlies low breast cancer incidence in Japan Lancet 354 1787-1788 PMID: 10577642 doi:10.1016/S0140-6736(99)04936-3

22. Leygue E, Dotzlaw H, Watson PH and Murphy LC (1998) Altered estrogen receptor alpha and beta messenger RNA expression during human breast tumourigenesis Cancer Res 58 3197-3201 PMID: 9699641

23. Shyamala G, Yang X, Cardiff RD and Dale E (2000) Impact of progesterone receptor on cell-fate decisions during mammary gland development Proc Natl Acad Sci USA 97 3044-3049 PMID: 10737785 doi:10.1073/pnas.97. 7.3044

24. McGowan EM and Clarke CL (1999) Effect of overexpression of progesterone receptor $A$ on endogenous progestin-sensitive endpoints in breast cancer cells Mol Endocrinol 13 1657-1671 PMID: $\underline{10517668}$ doi:10.1210/me.13.10.1657

25. Graham JD, Yeates C, Balleine RL, Harvey SS, Milliken JS, Bilous AM and Clarke CL (1995) Characterization of progesterone receptor $A$ and $B$ expression in human breast cancer Cancer Res 55 5063-5068 PMID: 7585552

26. Mote PA, Bartow S, Tran N and Clarke CL (2002) Loss of co-ordinate expression of progesterone receptors $A$ and $B$ is an early event in breast carcinogenesis Breast Cancer Res Treat 72 163-172 PMID: 12038707 doi:10.1023/A:1014820500738

27. Lea OA, Kvinnsland $S$ and Thorsen $T$ (1989) Improved measurement of androgen receptors in human breast cancer Cancer Res 49 7162-7167 PMID: 2582456

28. Kuenen-Boumeester V, Van der Kwast TH, Claassen CC, Look MP, Liem GS, Klijn JG and Henzen-Logmans SC (1996) The clinical significance of androgen receptors in breast cancer and their relation to histological and cell biological parameters Eur J Cancer 32A 1560-1565 PMID: 8911118 doi:10.1016/0959-8049(96)00112-8

29. Agoff SN, Swanson PE, Linden H, Hawes SE and Lawton TJ (2003) Androgen receptor expression in estrogen receptor-negative breast cancer. Immunohistochemical, clinical, and prognostic associations. Am J Clin Pathol 120 725-731 PMID: $\underline{14608899}$ doi:10.1309/42F00D0DJD0J5EDT

30. Brys $\mathrm{M}$, Wojcik $\mathrm{M}$, Romanowicz-Makowska $\mathrm{H}$ and Krajewska WM (2002) Androgen receptor status in female breast cancer:RT-PCR and Western blot studies J Cancer Res Clin Oncol 128 85-90 PMID: 11862478 doi:10.1007/s004320100294

31. Bieche I, Parfait B, Tozlu S, Lidereau R and Vidaud M (2001) Quantitation of androgen receptor gene expression in sporadic breast tumours by real-time RTPCR:evidence that MYC is an AR-regulated gene
Carcinogenesis 22 1521-1526 PMID: 11532875 doi: 10.1093/carcin/22.9.1521

32. Gonzalez LO, Pidal I, Junquera S, Corte MD, Vazquez J, Rodriguez JC, Lamelas ML, Merino AM, Garcia-Muniz JL and Vizoso FJ (2007) Overexpression of matrix metalloproteinases and their inhibitors in mononuclear inflammatory cells in breast cancer correlates with metastasis-relapse $\mathrm{Br} \mathrm{J}$ Cancer 97 957-963 PMID: $\underline{17848954}$ doi:10.1038/sj.bjc.6603935

33. Soreide JA, Lea OA, Varhaug JE, Skarstein A and Kvinnsland S (1992) Androgen receptors in operable breast cancer:relation to other steroid hormone receptors, correlations to prognostic factors and predictive value for effect of adjuvant tamoxifen treatment Eur J Surg Oncol 18 112-118 PMID: 1582503

34. Hankinson SE, Willett WC, Manson JE, Colditz GA, Hunter DJ, Spiegelman D, Barbieri RL and Speizer FE (1998) Plasma sex steroid hormone levels and risk of breast cancer in postmenopausal women J Natl Cancer Inst 90 1292-1299 PMID: 9731736 doi:10.1093/jnci/90.17.1292

35. Kaaks R, Berrino F, Key T, Rinaldi S, Dossus L et al (2005) Serum sex steroids in premenopausal women and breast cancer risk within the European Prospective Investigation into Cancer and Nutrition (EPIC) J Nat Cancer Inst 97 755-765 PMID: 15900045 doi:10.1093/inci/ diji32

36. Micheli A, Meneghini E, Secreto G, Berrino F, Venturelli E et al (2007) Plasma testosterone and prognosis of postmenopausal breast cancer patients $\mathrm{J}$ Clin Oncol 25 2685-2690 PMID: 17548841 doi:10.1200/JCO.2006.09. $\underline{0118}$

37. Wu K, DuPre E, Kim H, Tin U, Bissonnette RP, Lamph WW and Brown PH (2006) Receptor-selective retinoids inhibit the growth of normal and malignant breast cells by inducing $\mathbf{G 1}$ cell cycle blockade Breast Cancer Res Treat 96 147-157 PMID: 16273314 doi:10.1007/s10549005-9071-1

38. Pfahl M (1994) Vertebrate receptors:molecular biology, dimerization and response elements Semin Cell Biol 5 95-103 PMID: 8068887 doi:10.1006/scel.1994.1013

39. Mangelsdorf DJ and Evans RM (1995) The RXR heterodimers and orphan receptors Cell 83 841-850 PMID: 8521508 doi:10.1016/0092-8674(95)90200-7

40. Germain P, Chambon P, Eichele G, Evans RM, Lazar MA et al (2006) International Union of Pharmacology. LX. Retinoic acid receptors. Pharmacol Rev 58 712-725 PMID: 17132850 doi:10.1124/pr.58.4.4

41. Lotan R (1979) Different susceptibilities of human melanoma and breast carcinoma cell lines to retinoic acid-induced growth inhibition Cancer Res 391014 1019 PMID: 427741 
42. Toma S, Isnardi L, Raffo P, Dastoli G, De FE, Riccardi L, Palumbo R and Bollag W (1997) Effects of all-transretinoic acid and 13-cis-retinoic acid on breast-cancer cell lines:growth inhibition and apoptosis induction Int J Cancer 70 619-627 PMID: 9052765 doi:10.1002/(SICl) 1097-0215(19970304)70:53.0.CO;2-6

43. Bacus SS, Kiguchi K, Chin D, King CR and Huberman E (1990) Differentiation of cultured human breast cancer cells (AU-565 and MCF-7) associated with loss of cell surface HER-2/neu antigen Mol Carcinog 3 350-362 PMID: 1980588 doi:10.1002/mc.2940030607

44. van der Leede BM, Geertzema J, Vroom TM, Decimo D, Lutz Y, van der Saag PT and van der Burg B (1996) Immunohistochemical analysis of retinoic acid receptor-alpha in human breast tumours:retinoic acid receptor-alpha expression correlates with proliferative activity Am J Pathol 148 1905-1914 PMID: 8669476

45. Zhang XK, Liu Y and Lee MO (1996) Retinoid receptors in human lung cancer and breast cancer Mutat Res $\mathbf{3 5 0}$ 267-277 PMID: 8657191

46. Xu XC, Sneige N, Liu X, Nandagiri R, Lee JJ et al (1997) Progressive decrease in nuclear retinoic acid receptor beta messenger RNA level during breast carcinogenesis Cancer Res 57 4992-4996 PMID: $\underline{9371489}$

47. Grommes C, Landreth GE and Heneka MT (2004) Antineoplastic effects of peroxisome proliferatoractivated receptor gamma agonists Lancet Oncol 5419 429 PMID: 15231248 doi:10.1016/S1470-2045(04)01509-8

48. Koeffler HP (2003) Peroxisome proliferator-activated receptor gamma and cancers Clin Cancer Res 9 1-9 PMID: 12538445

49. Mueller E, Sarraf $P$, Tontonoz $P$, Evans RM, Martin KJ et al (1998) Terminal differentiation of human breast cancer through PPAR gamma Mol Cell 1 465-470 PMID: 9660931 doi:10.1016/S1097-2765(00)80047-7

50. Fajas L, Debril MB and Auwerx J (2001) Peroxisome proliferator-activated receptor-gamma:from adipogenesis to carcinogenesis $\mathrm{J} \mathrm{Mol} \mathrm{Endocrinol} 27$ 1-9 PMID: 11463572 doi:10.1677/jme.0.0270001

51. Murphy GJ and Holder JC (2000) PPAR-gamma agonists:therapeutic role in diabetes, inflammation and cancer Trends Pharmacol Sci 21 469-474 PMID: 11121836 doi:10.1016/S0165-6147(00)01559-5

52. Saez E, Rosenfeld J, Livolsi A, Olson P, Lombardo E et al (2004) PPAR gamma signaling exacerbates mammary gland tumour development Genes Dev 18 528-540 PMID: 15037548 doi:10.1101/gad.1167804

53. Nunez NP, Liu H and Meadows GG (2006) PPAR-gamma ligands and amino acid deprivation promote apoptosis of melanoma, prostate, and breast cancer cells Cancer Lett 236 133-141 PMID: 15979236 doi:10.1016/j.canlet. 2005.05.009

54. Papadaki I, Mylona E, Giannopoulou I, Markaki S, Keramopoulos A and Nakopoulou L (2005) PPARgamma expression in breast cancer:clinical value and correlation with ERbeta Histopathology 46 37-42 PMID: 15656884 doi:10.1111/j.1365-2559.2005.02056.x

55. Veronesi U, De Palo G, Marubini E, Costa A, Formelli F et al (1999) Randomized trial of fenretinide to prevent second breast malignancy in women with early breast cancer J Natl Cancer Inst 91 1847-1856 PMID: 10547391 doi:10.1093/inci/91.21.1847

56. Lefebvre MF, Guillot C, Crepin M and Saez S (1995) Influence of tumour derived fibroblasts and 1,25dihydroxyvitamin D3 on growth of breast cancer cell lines Breast Cancer Res Treat 33 189-197 PMID: 7749146 doi:10.1007/BF00665943

57. Simboli-Campbell $M$, Narvaez $C J$, Tenniswood $M$ and Welsh J (1996) 1,25-Dihydroxyvitamin D3 induces morphological and biochemical markers of apoptosis in MCF-7 breast cancer cells J Steroid Biochem Mol Biol 58 367-376 PMID: 8903420 doi:10.1016/0960-0760(96) $\underline{00055-6}$

58. Kanazawa T, Enami J and Kohmoto K (1999) Effects of 1alpha,25-dihydroxycholecalciferol and cortisol on the growth and differentiation of primary cultures of mouse mammary epithelial cells in collagen gel Cell Biol Int 23 481-487 PMID: 10728785 doi:10.1006/cbir.1999.0406

59. Narvaez CJ and Welsh J (2001) Role of mitochondria and caspases in vitamin D-mediated apoptosis of MCF7 breast cancer cells J Biol Chem 276 9101-9107 PMID: 11053435 doi:10.1074/jbc.M006876200

60. Colston KW, Berger U and Coombes RC (1989) Possible role for vitamin $D$ in controlling breast cancer cell proliferation Lancet 1 188-191 PMID: 2563099 doi:10.1016/S0140-6736(89)91204-X

61. Anzano MA, Smith JM, Uskokovic MR, Peer CW, Mullen LT et al (1994) 1 alpha,25-Dihydroxy-16-ene-23-yne-26,27hexafluorocholecalciferol (Ro24-5531), a new deltanoid (vitamin D analogue) for prevention of breast cancer in the rat Cancer Res 54 1653-1656 PMID: 8137276

62. Conde I, Paniagua R, Fraile B, Ruiz A and Arenas MI (2004) Expression of vitamin D3 receptor and retinoid receptors in human breast cancer:identification of potential heterodimeric receptors Int J Oncol 251183 1191 PMID: 15375571

63. Friedrich $\mathrm{M}$, Rafi L, Tilgen $\mathrm{W}$, Schmidt $\mathrm{W}$ and Reichrath $\mathrm{J}$ (1998) Expression of 1,25-dihydroxy vitamin D3 receptor in breast carcinoma $J$ Histochem Cytochem 46 1335-1337 PMID: 9774633 
64. Berger U, McClelland RA, Wilson P, Greene GL, Haussler MR et al (1991) Immunocytochemical determination of estrogen receptor, progesterone receptor, and 1,25dihydroxyvitamin D3 receptor in breast cancer and relationship to prognosis Cancer Res 51 239-244 PMID: $\underline{1846309}$

65. Shin MH, Holmes MD, Hankinson SE, Wu K, Colditz GA and Willett WC (2002) Intake of dairy products, calcium, and vitamin $\mathbf{d}$ and risk of breast cancer $\mathrm{J}$ Natl Cancer Inst 94 1301-1311 PMID: 12208895

66. Knekt P, Jarvinen R, Seppanen R, Pukkala E and Aromaa $A$ (1996) Intake of dairy products and the risk of breast cancer Br J Cancer 73 687-691 PMID: 8605108

67. John EM, Schwartz GG, Dreon DM and Koo J (1999) Vitamin D and breast cancer risk:the NHANES I Epidemiologic follow-up study, 1971-1975 to 1992. National Health and Nutrition Examination Survey Cancer Epidemiol Biomarkers Prev 8 399-406 PMID: 10350434

68. Mawer EB, Walls J, Howell A, Davies M, Ratcliffe WA and Bundred NJ (1997) Serum 1,25-dihydroxyvitamin D may be related inversely to disease activity in breast cancer patients with bone metastases $\mathrm{J}$ Clin Endocrinol Metab 82 118-122 PMID: 8989244 doi:10.1210/jc.82.1.118

69. Janowsky EC, Lester GE, Weinberg CR, Millikan RC, Schildkraut JM, Garrett PA and Hulka BS (1999) Association between low levels of 1,25dihydroxyvitamin D and breast cancer risk Public Health Nutr 2 283-291 PMID: 10512563 doi:10.1017/ $\underline{\mathrm{S} 1368980099000385}$

70. Guyton KZ, Kensler TW and Posner GH (2003) Vitamin D and vitamin $D$ analogs as cancer chemopreventive agents Nutr Rev 61 227-238 PMID: 12918875 doi:10.1301/nr.2003.jul.227-238

71. Andrechek ER and Muller WJ (2000) Tyrosine kinase signalling in breast cancer:tyrosine kinase-mediated signal transduction in transgenic mouse models of human breast cancer Breast Cancer Res 2 211-216 PMID: 11250712 doi:10.1186/bcr56

72. Blume-Jensen $P$ and Hunter $T$ (2001) Oncogenic kinase signalling Nature 411 355-365 PMID: 11357143 $\underline{\text { doi: } 10.1038 / 35077225}$

73. Gschwind A, Fischer OM and Ullrich A (2004) The discovery of receptor tyrosine kinases:targets for cancer therapy Nat Rev Cancer 4 361-370 PMID: $\underline{15122207}$ doi:10.1038/nrc1360

74. Nicholson RI, Gee JM and Harper ME (2001) EGFR and cancer prognosis Eur J Cancer 37 Suppl 4 S9-15 doi:10.1016/S0959-8049(01)00231-3
75. Holbro T, Civenni $G$ and Hynes NE (2003) The ErbB receptors and their role in cancer progression Exp Cell Res 284 99-110 PMID: 12648469 doi:10.1016/S00144827(02)00099-X

76. Klijn JG, Berns PM, Schmitz PI and Foekens JA (1992) The clinical significance of epidermal growth factor receptor (EGF-R) in human breast cancer:a review on 5232 patients Endocr Rev 13 3-17 PMID: 1313356 doi:10.1210/er.13.1.3

77. Ethier SP (1995) Growth factor synthesis and human breast cancer progression J Natl Cancer Inst 87 964-973 PMID: 7629883 doi:10.1093/jnci/87.13.964

78. van AT, Timmermans $M$, Foekens JA, Dorssers LC, Henzen-Logmans SC (1994) Differential expression of estrogen, progesterone, and epidermal growth factor receptors in normal, benign, and malignant human breast tissues using dual staining immunohistochemistry Am J Pathol 144 1238-1246 PMID: 7515559

79. Fabian CJ, Zalles C, Kamel S, Kimler BF, McKittrick R et al (1994) Prevalence of aneuploidy, overexpressed ER, and overexpressed EGFR in random breast aspirates of women at high and low risk for breast cancer Breast Cancer Res Treat 30 263-274 PMID: 7981444 doi:10.1007/BF00665967

80. Slamon DJ, Clark GM, Wong SG, Levin WJ, Ullrich A and McGuire WL (1987) Human breast cancer:correlation of relapse and survival with amplification of the HER2/neu oncogene Science 235 177-182 PMID: 3798106 doi:10.1126/science.3798106

81. Ross JS and Fletcher JA (1998) The HER-2/neu Oncogene in Breast Cancer:Prognostic Factor, Predictive Factor, and Target for Therapy Oncologist 3 237-252 PMID: 10388110

82. Ropero S, Menendez JA, Vazquez-Martin A, Montero S, Cortes-Funes $\mathrm{H}$ and Colomer R (2004) Trastuzumab plus tamoxifen:anti-proliferative and molecular interactions in breast carcinoma Breast Cancer Res Treat 86125-137 PMID: 15319565 doi:10.1023/B:BREA.0000032981.20384. c6

83. Gago FE, Fanelli MA and Ciocca DR (2006) Coexpression of steroid hormone receptors (estrogen receptor alpha and/or progesterone receptors) and Her2/neu (c-erbB-2) in breast cancer:clinical outcome following tamoxifen-based adjuvant therapy J Steroid Biochem Mol Biol 98 36-40 PMID: 16188438 doi:10.1016/ j.jsbmb.2005.07.002

84. Sassen A, Rochon J, Wild P, Hartmann A, Hofstaedter F, Schwarz S and Brockhoff G (2008) Cytogenetic analysis of HER1/EGFR, HER2, HER3 and HER4 in 278 breast cancer patients Breast Cancer Res 10 R2 PMID: $\underline{18182100}$ doi:10.1186/bcr1843 
85. Neve RM, Sutterluty H, Pullen N, Lane HA, Daly JM, Krek $W$ and Hynes NE (2000) Effects of oncogenic ErbB2 on G1 cell cycle regulators in breast tumour cells Oncogene 19 1647-1656 PMID: 10763821 doi:10.1038/sj. onc. 1203470

86. Liu B, Ordonez-Ercan D, Fan Z, Edgerton SM, Yang $X$ and Thor AD (2007) Downregulation of erbB3 abrogates erbB2-mediated tamoxifen resistance in breast cancer cells Int J Cancer 120 1874-1882 PMID: 17266042 doi:10.1002/ijc.22423

87. Kong A, Calleja V, Leboucher P, Harris A, Parker PJ and Larijani B (2008) HER2 oncogenic function escapes EGFR tyrosine kinase inhibitors via activation of alternative HER receptors in breast cancer cells PLOS ONE 3 e2881 PMID: 18682844 doi:10.1371/journal.pone. $\underline{0002881}$

88. Witton CJ, Reeves JR, Going JJ, Cooke TG and Bartlett JM (2003) Expression of the HER1-4 family of receptor tyrosine kinases in breast cancer J Pathol 200 290-297 PMID: 12845624 doi:10.1002/path.1370

89. Hudelist G, Singer CF, Manavi M, Pischinger K, Kubista E and Czerwenka K (2003) Co-expression of ErbB-family members in human breast cancer:Her-2/neu is the preferred dimerization candidate in nodal-positive tumours Breast Cancer Res Treat 80:353-361 PMID: 14503808 doi:10.1023/A:1024929522376

90. Fuchs IB, Siemer I, Buhler H, Schmider A, Henrich W, Lichtenegger W, Schaller G and Kuemmel S (2006) Epidermal growth factor receptor changes during breast cancer metastasis Anticancer Res 26 4397-4401 PMID: 17201160

91. Tovey SM, Witton CJ, Bartlett JM, Stanton PD, Reeves JR and Cooke TG (2004) Outcome and human epidermal growth factor receptor (HER) 1-4 status in invasive breast carcinomas with proliferation indices evaluated by bromodeoxyuridine labelling Breast Cancer Res 6 R246-R251 PMID: 15084248 doi:10.1186/bcr783

92. Vogt U, Bielawski K, Schlotter CM, Bosse U, Falkiewicz B and Podhajska AJ (1998) Amplification of erbB-4 oncogene occurs less frequently than that of erbB-2 in primary human breast cancer Gene 223 375-380 PMID: $\underline{9858771}$ doi:10.1016/S0378-1119(98)00454-5

93. Sartor $\mathrm{Cl}$, Zhou H, Kozlowska E, Guttridge K, Kawata E et al (2001) Her4 mediates ligand-dependent antiproliferative and differentiation responses in human breast cancer cells Mol Cell Biol 21 4265-4275 PMID: 11390655 doi:10.1128/MCB.21.13.4265-4275.2001

94. Moses HL, Yang EY and Pietenpol JA (1990) TGF-beta stimulation and inhibition of cell proliferation:new mechanistic insights Cell 63 245-247 PMID: 2208284 doi:10.1016/0092-8674(90)90155-8
95. Wakefield LM and Roberts AB (2002) TGF-beta signaling:positive and negative effects on tumourigenesis Curr Opin Genet Dev 12 22-29 PMID: 11790550 doi:10.1016/S0959-437X(01)00259-3

96. Derynck R, Akhurst RJ and Balmain A (2001) TGF-beta signaling in tumour suppression and cancer progression Nat Genet 29 117-129 PMID: 11586292 doi:10.1038/ng1001-117

97. Cohen MM, Jr (2003) TGF beta/Smad signaling system and its pathologic correlates Am J Med Genet A 116A 110 PMID: 12476444 doi:10.1002/ajmg.a.10750

98. Yingling JM, Blanchard $\mathrm{KL}$ and Sawyer JS (2004) Development of TGF-beta signalling inhibitors for cancer therapy Nat Rev Drug Discov 3 1011-1022 PMID: 15573100 doi:10.1038/nrd1580

99. Akhurst RJ (2006) Large- and small-molecule inhibitors of transforming growth factor-beta signalling Curr Opin Investig Drugs 7 513-521 PMID: 16784021

100. Ehata S, Hanyu A, Fujime M, Katsuno Y, Fukunaga E et al (2007) Ki26894, a novel transforming growth factorbeta type I receptor kinase inhibitor, inhibits in vitro invasion and in vivo bone metastasis of a human breast cancer cell line Cancer Sci 98 127-133 PMID: 17129361 doi:10.1111/j.1349-7006.2006.00357.x

101. Ge R, Rajeev V, Ray P, Lattime E, Rittling S et al (2006) Inhibition of growth and metastasis of mouse mammary carcinoma by selective inhibitor of transforming growth factor-beta type I receptor kinase in vivo Clin Cancer Res 12 4315-4330 PMID: 16857807 doi:10.1158/1078-0432.CCR-06-0162

102. Bandyopadhyay A, Agyin JK, Wang L, Tang Y, Lei X et al (2006) Inhibition of pulmonary and skeletal metastasis by a transforming growth factor-beta type I receptor kinase inhibitor Cancer Res 66 6714-6721 PMID: 16818646 doi:10.1158/0008-5472.CAN-05-3565

103. Wang Y, He QY, Chen H and Chiu JF (2007) Synergistic effects of retinoic acid and tamoxifen on human breast cancer cells:proteomic characterization Exp Cell Res 313 357-368 PMID: 17098229 doi:10.1016/j.yexcr.2006. $\underline{10.016}$

104. Yu H and Rohan T (2000) Role of the insulin-like growth factor family in cancer development and progression $\mathrm{J}$ Natl Cancer Inst 92 1472-1489 PMID: 10995803 doi:10.1093/jnci/92.18.1472

105. Pollak M (1998) IGF-I physiology and breast cancer Recent Results Cancer Res 152 63-70 PMID: 9928547

106. Surmacz E (2000) Function of the IGF-I receptor in breast cancer J Mammary Gland Biol Neoplasia 5 95-105 PMID: 10791772 doi:10.1023/A:1009523501499 
107. Sachdev D and Yee D (2007) Disrupting insulin-like growth factor signaling as a potential cancer therapy Mol Cancer Ther 6 1-12 PMID: 17237261 doi:10.1158/ 1535-7163.MCT-06-0080

108. Baxter RC (2001) Signalling pathways involved in antiproliferative effects of IGFBP-3:a review Mol Pathol 54 145-148 PMID: 11376125 doi:10.1136/mp.54.3.145

109. Martin JL and Baxter RC (1991) Transforming growth factor-beta stimulates production of insulin-like growth factor-binding protein-3 by human skin fibroblasts Endocrinology 128 1425-1433 PMID: 1705505 doi: 10.1210/endo-128-3-1425

110. Liu B, Lee HY, Weinzimer SA, Powell DR, Clifford JL, Kurie JM and Cohen P (2000) Direct functional interactions between insulin-like growth factor-binding protein-3 and retinoid $X$ receptor-alpha regulate transcriptional signaling and apoptosis J Biol Chem 275 33607-33613 PMID: 10874028 doi:10.1074/jbc.M002547200

111. Decensi A, Veronesi U, Miceli R, Johansson H, Mariani L et al (2003) Relationships between plasma insulin-like growth factor-I and insulin-like growth factor binding protein-3 and second breast cancer risk in a prevention trial of fenretinide Clin Cancer Res 9 4722-4729

112. Boland GP, Butt IS, Prasad R, Knox WF and Bundred NJ (2004) COX-2 expression is associated with an aggressive phenotype in ductal carcinoma in situ $\mathrm{Br} \mathrm{J}$ Cancer 90 423-429 PMID: 14735188 doi:10.1038/sj.bjc. $\underline{6601534}$

113. Shim JY, An HJ, Lee YH, Kim SK, Lee KP and Lee KS (2003) Overexpression of cyclooxygenase-2 is associated with breast carcinoma and its poor prognostic factors Mod Pathol 16 1199-1204 PMID: $\underline{14681319}$ doi:10.1097/01.MP.0000097372.73582.CB

114. Spizzo G, Gastl G, Wolf D, Gunsilius E, Steurer M et al (2003) Correlation of COX-2 and Ep-CAM overexpression in human invasive breast cancer and its impact on survival $\mathrm{Br} \mathrm{J}$ Cancer 88 574-578 PMID: $\underline{12592372}$ doi:10.1038/sj.bjc. 6600741

115. Wulfing P, Diallo R, Muller C, Wulfing C, Poremba C et al (2003) Analysis of cyclooxygenase-2 expression in human breast cancer:high throughput tissue microarray analysis J Cancer Res Clin Oncol 129 375382 PMID: 12884024 doi:10.1007/s00432-003-0459-1

116. Ristimaki A, Sivula A, Lundin J, Lundin M, Salminen T, Haglund C, Joensuu H and Isola J (2002) Prognostic significance of elevated cyclooxygenase-2 expression in breast cancer Cancer Res 62 632-635 PMID: $\underline{11830510}$

117. Subbaramaiah K, Norton L, Gerald W and Dannenberg AJ (2002) Cyclooxygenase-2 is overexpressed in HER2/neu-positive breast cancer:evidence for involvement of AP-1 and PEA3 J Biol Chem 27718649-18657 PMID: 11901151 doi:10.1074/ibc.M111415200

118. Cotterchio M, Kreiger N, Sloan M and Steingart A (2001) Nonsteroidal anti-inflammatory drug use and breast cancer risk Cancer Epidemiol Biomarkers Prev 10 12131217 PMID: 11700271

119. Khuder SA and Mutgi $A B$ (2001) Breast cancer and NSAID use:a meta-analysis $B r \mathrm{~J}$ Cancer 84 1188-1192 PMID: 11336469 doi:10.1054/bjoc.2000.1709

120. Harris RE, Beebe-Donk J and Alshafie GA (2006) Reduction in the risk of human breast cancer by selective cyclooxygenase-2 (COX-2) inhibitors $B M C$ Cancer 627 PMID: 16445867 doi:10.1186/1471-2407-6-27

121. Lanza-Jacoby S, Miller S, Flynn J, Gallatig K, Daskalakis C et al (2003) The cyclooxygenase-2 inhibitor, celecoxib, prevents the development of mammary tumours in Her2/neu mice Cancer Epidemiol Biomarkers Prev 1214861491 PMID: 14693742

122. Alshafie GA, bou-Issa HM, Seibert K and Harris RE (2000) Chemotherapeutic evaluation of Celecoxib, a cyclooxygenase-2 inhibitor, in a rat mammary tumour model Oncol Rep 7 1377-1381 PMID: 11032948

123. Grosser T, Fries S and FitzGerald GA (2006) Biological basis for the cardiovascular consequences of COX-2 inhibition:therapeutic challenges and opportunities $J$ Clin Invest 116 4-15 PMID: 16395396 doi:10.1172/ JCl27291

124. Sauter ER, Qin W, Schlatter L, Hewett JE and Flynn JT (2006) Celecoxib decreases prostaglandin E2 concentrations in nipple aspirate fluid from high risk postmenopausal women and women with breast cancer BMC Cancer 6248 PMID: 17049084 doi:10.1186/ $\underline{1471-2407-6-248}$

125. Hojilla CV, Wood GA and Khokha R (2008) Inflammation and breast cancer: metalloproteinases as common effectors of inflammation and extracellular matrix breakdown in breast cancer Breast Cancer Res 10205 PMID: 18394187 doi:10.1186/bcr1980

126. Hojilla CV, Mohammed FF and Khokha R (2003) Matrix metalloproteinases and their tissue inhibitors direct cell fate during cancer development $\mathrm{Br} \mathrm{J}$ Cancer 89 1817-1821 PMID: 14612884 doi:10.1038/sj.bjc.6601327

127. Li HC, Cao DC, Liu Y, Hou YF, Wu J et al (2004) Prognostic value of matrix metalloproteinases (MMP-2 and MMP-9) in patients with lymph node-negative breast carcinoma Breast Cancer Res Treat 88 75-85 PMID: 15538048 doi:10.1007/s10549-004-1200-8

128. Pellikainen JM, Ropponen KM, Kataja VV, Kellokoski JK, Eskelinen MJ and Kosma VM (2004) Expression of matrix metalloproteinase (MMP)-2 and MMP-9 in breast cancer 
with a special reference to activator protein-2, HER2, and prognosis Clin Cancer Res 10 7621-7628 PMID: $\underline{15569994}$ doi:10.1158/1078-0432.CCR-04-1061

129. Poola I, DeWitty RL, Marshalleck JJ, Bhatnagar R, Abraham J and Leffall LD (2005) Identification of MMP-1 as a putative breast cancer predictive marker by global gene expression analysis Nat Med 11 481-483 PMID: $\underline{15864312}$ doi:10.1038/nm1243

130. Lipton A, Ali SM, Leitzel K, Demers L, Evans DB, Hamer P, Brown-Shimer S, Pierce K and Carney W (2007) Elevated plasma tissue inhibitor of metalloproteinase-1 level predicts decreased response and survival in metastatic breast cancer Cancer 109 1933-1939 PMID: 17407159 doi:10.1002/cncr.22637

131. Span PN, Lindberg RL, Manders P, Tjan-Heijnen VC, Heuvel JJ, Beex LV and Sweep CG (2004) Tissue inhibitors of metalloproteinase expression in human breast cancer:TIMP-3 is associated with adjuvant endocrine therapy success J Pathol 202 395-402 PMID: 15095266 doi:10.1002/path.1528

132. Edwards DR (2004) TIMP-3 and endocrine therapy of breast cancer: an apoptosis connection emerges $\mathrm{J}$ Pathol 202 391-394 doi:10.1002/path.1548

133. Kotzsch M, Farthmann J, Meye A, Fuessel S, Baretton G et al (2005) Prognostic relevance of uPAR-del4/5 and TIMP-3 mRNA expression levels in breast cancer Eur J Cancer 41 2760-2768 PMID: 16256342 doi:10.1016/j. eica.2005.09.002

134. Guo YP, Martin LJ, Hanna W, Banerjee D, Miller N, Fishell E, Khokha R and Boyd NF (2001) Growth factors and stromal matrix proteins associated with mammographic densities Cancer Epidemiol Biomarkers Prev 10 243-248 PMID: 11303594

135. Mochizuki $S$ and Okada $Y$ (2007) ADAMs in cancer cell proliferation and progression Cancer Sci 98 621-628 PMID: 17355265 doi:10.1111/j.1349-7006.2007.00434.x

136. Arribas J, Bech-Serra JJ and Santiago-Josefat B (2006) ADAMs, cell migration and cancer Cancer Metastasis Rev 25 57-68 PMID: 16680572 doi:10.1007/s10555-006$\underline{7889-6}$

137. Gabay C and Kushner I (1999) Acute-phase proteins and other systemic responses to inflammation $N$ Engl J Med 340 448-454 PMID: 9971870 doi:10.1056/ NEJM199902113400607

138. Robertson JF, Pearson D, Price MR, Selby C, Pearson J, Blamey RW and Howell A (1991) Prospective assessment of the role of five tumour markers in breast cancer Cancer Immunol Immunother 33 403-410 PMID: 1878893 doi:10.1007/BF01741602
139. Mortensen RF and Rudczynski AB (1982) Prognostic significance of serum CRP levels and lymphoid cell infiltrates in human breast cancer Oncology 39 129-133 PMID: 7078935 doi:10.1159/000225621

140. Albuquerque KV, Price MR, Badley RA, Jonrup I, Pearson D, Blamey RW and Robertson JF (1995) Pre-treatment serum levels of tumour markers in metastatic breast cancer:a prospective assessment of their role in predicting response to therapy and survival Eur J Surg Oncol 21 504-509 PMID: 7589594 doi:10.1016/S07487983(95)96935-7

141. McMillan DC, Elahi MM, Sattar N, Angerson WJ, Johnstone $\mathrm{J}$ and McArdle CS (2001) Measurement of the systemic inflammatory response predicts cancer-specific and non-cancer survival in patients with cancer Nutr Cancer 41 64-69 PMID: 12094630 doi:10.1207/S15327914NC41$\underline{1 \& 28}$

142. Al Murri AM, Bartlett JM, Canney PA, Doughty JC, Wilson $C$ and McMillan DC (2006) Evaluation of an inflammation-based prognostic score (GPS) in patients with metastatic breast cancer $\mathrm{Br} J$ Cancer 94 227-230 PMID: 16404432 doi:10.1038/sj.bjc.6602922

143. Siemes C, Visser LE, Coebergh JW, Splinter TA, Witteman JC et al (2006) C-reactive protein levels, variation in the C-reactive protein gene, and cancer risk: the Rotterdam Study J Clin Oncol 24 5216-5222 PMID: 17114654 doi:10.1200/JCO.2006.07.1381

144. Il'yasova D, Colbert LH, Harris TB, Newman AB, Bauer DC et al (2005) Circulating levels of inflammatory markers and cancer risk in the health aging and body composition cohort Cancer Epidemiol Biomarkers Prev 14 2413-2418 PMID: 16214925 doi:10.1158/10559965.EPI-05-0316

145. Trichopoulos D, Psaltopoulou T, Orfanos P, Trichopoulou A and Boffetta P (2006) Plasma C-reactive protein and risk of cancer: a prospective study from Greece Cancer Epidemiol Biomarkers Prev 15 381-384 PMID: 16492932 doi:10.1158/1055-9965.EPI-05-0626

146. Zhang SM, Lin J, Cook NR, Lee IM, Manson JE, Buring JE and Ridker PM (2007) C-reactive protein and risk of breast cancer $J$ Natl Cancer Inst 99 890-894 PMID: 17551149 doi:10.1093/jnci/djk202

147. Lithgow D, Nyamathi A, Elashoff D, Martinez-Maza O and Covington $C$ (2007) C-reactive protein in nipple aspirate fluid associated with Gail model factors Biol Res Nurs 9 108-116 PMID: 17909163 doi:10.1177/1099800407306426

148. Tuck AB, Chambers AF and Allan AL (2007) Osteopontin overexpression in breast cancer: knowledge gained and possible implications for clinical management $\mathrm{J}$ Cell Biochem 102 859-868 PMID: 17721886 doi:10.1002/jcb.21520 
149. Tuck AB, O'Malley FP, Singhal H, Harris JF, Tonkin KS, Kerkvliet N, Saad Z, Doig GS and Chambers AF (1998) Osteopontin expression in a group of lymph node negative breast cancer patients Int J Cancer 79 502-508 PMID: 9761120 doi:10.1002/(SICI)1097-0215(19981023) 79:53.0.CO;2-3

150. Rudland PS, Platt-Higgins A, El-Tanani M, De Silva RS et al (2002) Prognostic significance of the metastasisassociated protein osteopontin in human breast cancer Cancer Res 62 3417-3427 PMID: 12067984

151. Mirza M, Shaughnessy E, Hurley JK, Vanpatten KA, Pestano GA, He B and Weber GF (2008) Osteopontin-c is a selective marker of breast cancer Int J Cancer 122 889-897 PMID: 17960616 doi:10.1002/ijc.23204

152. Patani N, Jouhra F, Jiang W and Mokbel K (2008) Osteopontin expression profiles predict pathological and clinical outcome in breast cancer Anticancer Res 28 4105-4110 PMID: 19192668

153. Bramwell VH, Doig GS, Tuck AB, Wilson SM, Tonkin KS et al (2006) Serial plasma osteopontin levels have prognostic value in metastatic breast cancer Clin Cancer Res 12 3337-3343 PMID: 16740755 doi:10.1158/ 1078-0432.CCR-05-2354

154. Singhal H, Bautista DS, Tonkin KS, O'Malley FP, Tuck AB et al (1997) Elevated plasma osteopontin in metastatic breast cancer associated with increased tumour burden and decreased survival Clin Cancer Res 3 605611 PMID: 9815727

155. Salvesen GS and Duckett CS (2002) IAP proteins:blocking the road to death's door Nat Rev Mol Cell Biol 3 401-410 PMID: 12042762 doi:10.1038/nrm830

156. Altieri DC (2003) Validating survivin as a cancer therapeutic target Nat Rev Cancer 3 46-54 PMID: 12509766 doi:10.1038/nrc968

157. Velculescu VE, Madden SL, Zhang L, Lash AE, Yu J et al (1999) Analysis of human transcriptomes Nat Genet 23 387-388 PMID: 10581018 doi:10.1038/70487

158. Idenoue S, Hirohashi $\mathrm{Y}$, Torigoe $\mathrm{T}$, Sato $\mathrm{Y}$, Tamura $\mathrm{Y}$ et al (2005) A potent immunogenic general cancer vaccine that targets survivin, an inhibitor of apoptosis proteins Clin Cancer Res 11 1474-1482 PMID: 15746049 doi:10.1158/1078-0432.CCR-03-0817

159. Paik S, Shak S, Tang G, Kim C, Baker J et al (2004) A multigene assay to predict recurrence of tamoxifentreated, node-negative breast cancer $N$ Engl J Med 351 2817-2826 PMID: 15591335 doi:10.1056/NEJMoa041588

160. Gritsko T, Williams A, Turkson J, Kaneko S, Bowman T et al (2006) Persistent activation of stat3 signaling induces survivin gene expression and confers resistance to apoptosis in human breast cancer cells
Clin Cancer Res 12 11-19 PMID: 16397018 doi:10.1158/ 1078-0432.CCR-04-1752

161. Xia W, Bisi J, Strum J, Liu L, Carrick K et al (2006) Regulation of survivin by ErbB2 signaling:therapeutic implications for ErbB2-overexpressing breast cancers Cancer Res 66 1640-1647 PMID: 16452223 doi:10.1158/ 0008-5472.CAN-05-2000

162. Chu JS, Shew JY and Huang CS (2004) Immunohistochemical analysis of survivin expression in primary breast cancers J Formos Med Assoc 103 925931 PMID: 15624042

163. Kayaselcuk F, Nursal TZ, Polat A, Noyan T, Yildirim S, Tarim A and Seydioglu G (2004) Expression of survivin, bcl-2, P53 and bax in breast carcinoma and ductal intraepithelial neoplasia (DIN 1a) J Exp Clin Cancer Res 23 105-112 PMID: 15149158

164. Goksel G, Taneli F, Uslu R, Ulman C, Dinc G, Coskun T and Kandiloglu AR (2007) Serum her-2/neu and survivin levels and their relationship to histological parameters in early-stage breast cancer $\mathrm{J}$ Int Med Res 35 165-172 PMID: 17542404

165. Ryan BM, Konecny GE, Kahlert S, Wang HJ, Untch M et al (2006) Survivin expression in breast cancer predicts clinical outcome and is associated with HER2, VEGF, urokinase plasminogen activator and PAI-1 Ann Oncol 17 597-604 PMID: 16403812 doi:10.1093/annonc/mdj121

166. Hinnis AR, Luckett JC and Walker RA (2007) Survivin is an independent predictor of short-term survival in poor prognostic breast cancer patients $\mathrm{Br} \mathrm{J}$ Cancer 96639 645 PMID: 17285125 doi:10.1038/sj.bjc. 6603616

167. Vousden $\mathrm{KH}$ and Lu X (2002) Live or let die:the cell's response to p53 Nat Rev Cancer 2 594-604 PMID: 12154352 doi:10.1038/nrc864

168. Vogelstein B, Lane D and Levine AJ (2000) Surfing the p53 network Nature 408 307-310 PMID: 11099028 $\underline{\text { doi:10.1038/35042675 }}$

169. Miller LD, Smeds J, George J, Vega VB, Vergara L et al (2005) An expression signature for p53 status in human breast cancer predicts mutation status, transcriptional effects, and patient survival Proc Natl Acad Sci USA 102 13550-13555 PMID: 16141321 doi:10.1073/pnas. $\underline{0506230102}$

170. Olivier M, Langerod A, Carrieri P, Bergh J, Klaar S et al (2006) The clinical value of somatic TP53 gene mutations in 1,794 patients with breast cancer Clin Cancer Res 12 1157-1167 PMID: 16489069 doi:10.1158/ 1078-0432.CCR-05-1029

171. Bull SB, Ozcelik H, Pinnaduwage $D$, Blackstein ME, Sutherland DA et al (2004) The combination of p53 mutation and neu/erbB-2 amplification is associated 
with poor survival in node-negative breast cancer $\mathrm{J}$ Clin Oncol 22 86-96 PMID: 14701769 doi:10.1200/JCO. $\underline{2004.09 .128}$

172. Muller M, Meyer M, Schilling T, Ulsperger E, Lehnert T et al (2006) Testing for anti-p53 antibodies increases the diagnostic sensitivity of conventional tumour markers Int J Oncol 29 973-980 PMID: 16964393

173. Lenner P, Wiklund F, Emdin SO, Arnerlov C, Eklund C, Hallmans G, Zentgraf H and Dillner J (1999) Serum antibodies against p53 in relation to cancer risk and prognosis in breast cancer:a population-based epidemiological study $\mathrm{Br} \mathrm{J}$ Cancer 79 927-932 PMID: $\underline{10070892}$ doi:10.1038/sj.bjc. 6690148

174. Mudenda B, Green JA, Green B, Jenkins JR, Robertson L et al (1994) The relationship between serum p53 autoantibodies and characteristics of human breast cancer Br J Cancer 69 1115-1119 PMID: 8198980

175. Gao RJ, Bao HZ, Yang Q, Cong Q, Song JN and Wang L (2005) The presence of serum anti-p53 antibodies from patients with invasive ductal carcinoma of breast:correlation to other clinical and biological parameters Breast Cancer Res Treat 93 111-115 PMID: 16187230 doi:10.1007/s10549-005-4321-9

176. Weinstat-Saslow D, Merino MJ, Manrow RE, Lawrence JA, Bluth RF et al (1995) Overexpression of cyclin D mRNA distinguishes invasive and in situ breast carcinomas from non-malignant lesions Nat Med 1 1257-1260 PMID: $\underline{7489405}$ doi:10.1038/nm1295-1257

177. Simpson JF, Quan DE, O'Malley F, Odom-Maryon T and Clarke PE (1997) Amplification of CCND1 and expression of its protein product, cyclin D1, in ductal carcinoma in situ of the breast Am J Pathol 151 161-168 PMID: 9212742

178. Gillett CE, Lee AH, Millis RR and Barnes DM (1998) Cyclin D1 and associated proteins in mammary ductal carcinoma in situ and atypical ductal hyperplasia $J$ Pathol 184 396-400 PMID: 9664905 doi:10.1002/(SICl) 1096-9896(199804)184:43.0.CO;2-G

179. Gillett C, Smith P, Gregory W, Richards M, Millis R et al (1996) Cyclin D1 and prognosis in human breast cancer Int J Cancer 69 92-99 PMID: 8608989 doi:10.1002/ (SICl)1097-0215(19960422)69:23.0.CO;2-Q

180. Hwang TS, Han HS, Hong YC, Lee HJ and Paik NS (2003) Prognostic value of combined analysis of cyclin D1 and estrogen receptor status in breast cancer patients Pathol Int 53 74-80 PMID: 12588434 doi:10.1046/.14401827.2003.01441.x

181. Neuman E, Ladha MH, Lin N, Upton TM, Miller SJ et al (1997) Cyclin D1 stimulation of estrogen receptor transcriptional activity independent of cdk4 Mol Cell Biol 17 5338-5347 PMID: 9271411
182. Zhou Q, Stetler-Stevenson M and Steeg PS (1997) Inhibition of cyclin D expression in human breast carcinoma cells by retinoids in vitro Oncogene $15107-$ 115 PMID: 9233783 doi:10.1038/sj.onc.1201142

183. Kim HT, Kong G, Denardo D, Li Y, Uray I et al (2006) Identification of biomarkers modulated by the rexinoid LGD1069 (bexarotene) in human breast cells using oligonucleotide arrays Cancer Res 6612009-12018. PMID: 17178900 doi:10.1158/0008-5472.CAN-05-2515

184. Veronesi U, Mariani L, Decensi A, Formelli F, Camerini T et al (2006) Fifteen-year results of a randomized phase III trial of fenretinide to prevent second breast cancer $A n n$ Oncol 17 1065-1071 PMID: 16675486 doi:10.1093/ annonc/mdl047

185. Banerjee S, Dowsett M, Ashworth A and Martin LA (2007) Mechanisms of disease:angiogenesis and the management of breast cancer Nat Clin Pract Oncol 4 536-550 PMID: 17728712 doi:10.1038/ncponc0905

186. Linderholm B, Grankvist K, Wilking N, Johansson M, Tavelin B and Henriksson R (2000) Correlation of vascular endothelial growth factor content with recurrences, survival, and first relapse site in primary node-positive breast carcinoma after adjuvant treatment J Clin Oncol 18 1423-1431 PMID: 10735889

187. Adams J, Carder PJ, Downey S, Forbes MA, MacLennan K et al (2000) Vascular endothelial growth factor (VEGF) in breast cancer:comparison of plasma, serum, and tissue VEGF and microvessel density and effects of tamoxifen Cancer Res 60 2898-2905 PMID: 10850435

188. Heer K, Kumar H, Read JR, Fox JN, Monson JR and Kerin MJ (2001) Serum vascular endothelial growth factor in breast cancer:its relation with cancer type and estrogen receptor status Clin Cancer Res 7 3491-3494 PMID: 11705867

189. Wu Y, Saldana L, Chillar R and Vadgama JV (2002) Plasma vascular endothelial growth factor is useful in assessing progression of breast cancer post surgery and during adjuvant treatment Int $\mathrm{J}$ Oncol 20 509-516 PMID: 11836562

190. Hieken TJ, Farolan M, D'Alessandro S and Velasco JM (2001) Predicting the biologic behavior of ductal carcinoma in situ:an analysis of molecular markers Surgery 130 593-600 PMID: 11602889 doi:10.1067/msy. 2001.116921

191. Pavlakis K, Messini I, Vrekoussis T, Yiannou P, Keramopoullos D et al (2008) The assessment of angiogenesis and fibroblastic stromagenesis in hyperplastic and pre-invasive breast lesions $B M C$ Cancer 888 PMID: 18384688 doi:10.1186/1471-2407-8-88

192. Hyder SM (2006) Sex-steroid regulation of vascular endothelial growth factor in breast cancer Endocr Relat 
Cancer 13 667-687 PMID: 16954424 doi:10.1677/erc. 1.00931

193. Garvin S, Nilsson UW, Dabrosin C. (2005) Effects of oestradiol and tamoxifen on VEGF, soluble VEGFR-1, and VEGFR-2 in breast cancer and endothelial cells. $\mathrm{Br}$ J Cancer 93:1005-1010. PMID: 16234819 doi:10.1038/sj. bjc. 6602824

194. Beresford MJ, Wilson GD and Makris A (2006) Measuring proliferation in breast cancer:practicalities and applications Breast Cancer Res 8216 PMID: 17164010 doi:10.1186/bcr1618

195. Clayton F (1991) Pathologic correlates of survival in $\mathbf{3 7 8}$ lymph node-negative infiltrating ductal breast carcinomas. Mitotic count is the best single predictor Cancer 68 1309-1317 PMID: 1651805 doi:10.1002/10970142(19910915)68:63.0.CO;2-I

196. van Diest PJ, van der WE and Baak JP (2004) Prognostic value of proliferation in invasive breast cancer:a review J Clin Pathol 57 675-681 PMID: 15220356 doi:10.1136/ jcp.2003.010777

197. Barnard NJ, Hall PA, Lemoine NR and Kadar N (1987) Proliferative index in breast carcinoma determined in situ by Ki67 immunostaining and its relationship to clinical and pathological variables J Pathol 152 287-295 PMID: 3668731 doi:10.1002/path.1711520407

198. Parrado C, Falkmer UG, Hoog A, Falkmer S, Ahrens O, Rius $F$ and Grimelius $L$ (1996) A technique for automatic/interactive assessment of the proliferating fraction of neoplastic cells in solid tumours. A methodological study on the Ki-67 immunoreactive cells in human mammary carcinomas, including a comparison with the results of conventional S-phase fraction assessments by means of DNA cytometry Gen Diagn Pathol 141 215-227 PMID: 8705786

199. Molino A, Micciolo R, Turazza M, Bonetti F, Piubello Q et al (1997) Ki-67 immunostaining in 322 primary breast cancers:associations with clinical and pathological variables and prognosis Int J Cancer 74 433-437. PMID: $\underline{9291434}$ doi:10.1002/(SICI)1097-0215(19970822)74:43.0. CO;2-A

200. Jansen RL, Hupperets PS, Arends JW, Joosten-Achjanie SR, Volovics A, Schouten HC and Hillen HF (1998) MIB-1 labelling index is an independent prognostic marker in primary breast cancer $\mathrm{Br} J$ Cancer 78 460-465 PMID: $\underline{9716027}$

201. Goodson WH, III, Moore DH, Ljung BM, Chew K, Mayall B, Smith HS and Waldman FM (2000) The prognostic value of proliferation indices: a study with in vivo bromodeoxyuridine and Ki-67 Breast Cancer Res Treat 59 113-123 PMID: 10817346 doi:10.1023/A: 1006344010050

202. Clarke RB, Laidlaw IJ, Jones LJ, Howell A and Anderson E (1993) Effect of tamoxifen on Ki67 labelling index in human breast tumours and its relationship to oestrogen and progesterone receptor status $\mathrm{Br} J$ Cancer 67 606-611 PMID: 8439511

203. Johnston SR, MacLennan KA, Sacks NP, Salter J, Smith IE and Dowsett M (1994) Modulation of Bcl-2 and Ki-67 expression in oestrogen receptor-positive human breast cancer by tamoxifen Eur J Cancer 30A 16631669 PMID: 7833141 doi:10.1016/0959-8049(94)00327-2

204. Makris A, Powles TJ, Allred DC, Ashley S, Ormerod MG, Titley JC and Dowsett M (1998) Changes in hormone receptors and proliferation markers in tamoxifen treated breast cancer patients and the relationship with response Breast Cancer Res Treat 48 11-20 PMID: 9541185 doi:10.1023/A:1005973529921

205. The ATAC (Arimidex TaoiCTG) (2002) Anastrozole alone or in combination with tamoxifen versus tamoxifen alone for adjuvant treatment of postmenopausal women with early breast cancer: first results of the ATAC randomised trial Lancet 359 2131-2139 PMID: $\underline{12090977}$ doi:10.1016/S0140-6736(02)09088-8

206. Cazzaniga M, Severi G, Casadio C, Chiapparini L, Veronesi $U$ and Decensi A (2006) Atypia and Ki-67 expression from ductal lavage in women at different risk for breast cancer Cancer Epidemiol Biomarkers Prev 15 1311-1315 PMID: 16835329 doi:10.1158/1055-9965. EPI-05-0810

207. Khan QJ, Kimler BF, Clark J, Metheny T, Zalles CM and Fabian CJ (2005) Ki-67 expression in benign breast ductal cells obtained by random periareolar fine needle aspiration Cancer Epidemiol Biomarkers Prev 14 786-789 PMID: 15824144 doi:10.1158/1055-9965.EPI-04-0239

208. Sullivan RP, Mortimer G and Muircheartaigh IO (1993) Cell proliferation in breast tumours:analysis of histological parameters Ki67 and PCNA expression Ir J Med Sci 162 343-347 PMID: 7903289 doi:10.1007/BF02942162 